\title{
Sri Lankan Tamil Refugees in India: Conceptual Framework of Repatriation Success
}

\author{
MIRIAM GEORGE, ANITA VAILLANCOURT, AND S. IRUDAYA RAJAN
}

\begin{abstract}
Repatriation to Sri Lanka has become a primary challenge to Sri Lankan Tamil refugees in Indian refugee camps, and a matter of significant public discussion in India and Sri Lanka. Anxiety about repatriation among Sri Lankan Tamil refugees and lack of initiation from the Sri Lankan government threatens the development of a coherent repatriation strategy. This article proposes a conceptual framework of repatriation success for Sri Lankan Tamil refugees, which the Sri Lankan government, non-governmental agencies, and Sri Lankan Tamil refugees may use to develop a concrete strategy for repatriation. Based upon the study results of two of the authors' repatriation studies, this article identifies and describes the four key concepts of the repatriation framework: livelihood development, language and culture awareness, social relationships, and equal citizenship within a nation.
\end{abstract}

\section{Résumé}

Le rapatriement vers le Sri Lanka constitue l'un des défis principaux que doivent affronter les réfugiés tamouls d'origine sri lankaise vivant dans les camps de réfugiés en Inde, et un sujet important de débats publics en Inde ainsi qu'au Sri Lanka. L'inquiétude envers le rapatriement parmi les réfugiés tamouls d'origine sri lankaise et l'absence de démarches de la part du gouvernement sri lankais compromet le développement d'une stratégie cohérente de rapatriement. L'objectif principal de cet article est de proposer un cadre conceptuel pour un rapatriement réussi à l'égard des réfugiés tamouls d'origine sri lankaise que le gouvernement sri lankais, les agences non gouvernementales et les réfugiés dont il est question pourraient utiliser afin de développer une stratégie concrète pour le rapatriement. Fondé sur les résultats provenant des études de recherche sur le rapatriement effectuées par deux des auteurs, l'article identifie et décrit les quatre concepts clés du cadre de rapatriement: le développement des moyens de subsistance, une prise de conscience linguistique et culturelle, les liens sociaux et l'égalité de la citoyenneté dans le contexte national.

\section{Introduction}

$\mathrm{S}$ ince Sri Lanka's independence from Britain in 1948, the Sinhalese and Tamil ethnic groups have had a conflictual relationship over control of northern Sri Lanka. ${ }^{1}$ The conflict between majority Sinhalese and minority Tamils in Sri Lanka resulted in three waves of Tamil refugee migration in 1984, 1999, and 2006. ${ }^{2}$ India has the highest number of Sri Lankan Tamils outside of Sri Lanka because India is geographically close to Sri Lanka. ${ }^{3}$ Of the 123 Sri Lankan Tamil refugee camps in India, 115 are in the Indian state of Tamil Nadu because there is a linguistic and ethnic kinship between Sri Lankan Tamils and Indian Tamils. ${ }^{4}$ For example, the main language of the state of Tamil Nadu is Tamil, which is also the primary language of Sri Lankan Tamils. 5 The Tamil Nadu state government provides support and resources for the welfare of Sri Lankan Tamil refugees living in refugee camps. ${ }^{6}$ However, the Indian government has refused to give refugee status, permanent resident status, or citizenship to Sri Lankan Tamil refugees, including 
refugee children who were born in India, primarily because the Indian government expected Tamil refugees to repatriate to Sri Lanka when the civil war ended. 7 The civil war ended in November 2009 and-according to the Ministry of Prison Reforms, Rehabilitation, Resettlement, and Hindu Religious Affairs in Sri Lanka-only 4,691 persons repatriated to Sri Lanka between 2011 and early 2016. ${ }^{8}$ Although India has recently signed several international treaties pertaining to the rights and protections of its citizens, Sanderson argues that they provide only some protections for refugees in India. 9 Regardless, India has not signed either the 1951 United Nations Refugee Convention or its 1967 Protocol, which has 140 signatories, an overwhelming majority of the world's nations. There has never been evidence of a forced repatriation from India, but not signing the Refugee Convention and Protocol is a blot on India's record. ${ }^{10}$ Additionally, Sri Lanka, although working with the United Nations High Commissioner for Refugees (UNHCR) to some extent, has refused to sign the 1951 United Nations Refugee Convention. ${ }^{11}$ As such, typical thought and interpretation of the law regarding the rights and responsibility of individuals' states of origin ${ }^{12}$ and host states is only very loosely applicable to the situation facing Tamil refugees in India. This has limited the assistance role of lead agencies such as the UNHCR, which led to restricted ad hoc protection and ambivalent international obligations to provide a successful repatriation program. Integration into local Indian society may be a durable solution for Tamil refugees, ${ }^{13}$ but the current situation of "refugee warehousing"14 in combination with India's ambiguous stance on international refugee issues are barriers in that process. ${ }^{15}$ Although resettlement into a third country may be an option for some Tamils, this too is complicated by pre-migration socio-economic status, social connections, and in some cases, safety in a third country. ${ }^{16}$

In light of the current situation, two of the authors conducted separate research on Sri Lankan Tamil refugees' repatriation and livelihood plans, and the results of these studies provide the basis for the development of a repatriation program as a durable solution for this population. This article does not emphasize the idea that "all refugees want to go home" or that "the best place for refugees is home."17 In fact, many factors could contribute to a Tamil's desire to stay in India, including the individual's understanding of India as home and perceived greater educational and livelihood opportunities. ${ }^{18}$ Instead, this article proposes a conceptual framework for the successful repatriation of Sri Lankan Tamil refugees based on the results of two research studies, which might be beneficial for the Sri Lankan government and non-governmental agencies designing repatriation programs for Sri Lankan Tamil refugees who want to return home.

\section{Repatriation and Sri Lankan Tamil Refugees}

Voluntary repatriation, which is often considered the optimal solution to refugees' problems, ${ }^{19}$ recognizes the right of the individual to safety and security and upholds the dignity of the individual's freedom of choice. Human rights and refugee laws and the agencies working under those laws are subject to promoting voluntary repatriation without any indication that host country or country of origin subscribes to those values. ${ }^{20}$ Allen stated that voluntary repatriation is the cheapest option without manipulating international assistance funds; therefore, repatriation is also a pragmatic response, overlooking the possibility of refugee integration into their exile country or a third country settlement as proposed by UNHCR, which is ethically ambiguous. ${ }^{21}$ Regardless, the voluntary nature of a refugee's decision to repatriate depends largely on the success of the repatriation program. A common expectation is that refugees will choose to repatriate once the reason for their departure has been resolved, ${ }^{22}$ without examining the infrastructures available to repatriates when they return to their homeland. Warner pointed out that voluntary repatriation indicates a return to a home and community with which refugees were associated and embraced before their flight into exile. ${ }^{23}$ As a corollary to these perceptions, institutions dealing with refugees tend to depict repatriation as a "homecoming" to a former life and a familiar cultural environment, as a straightforward way of restoring pre-displacement life in familiar settings. ${ }^{24}$ However, this assumption does not account for the myriad challenges that refugees often face during repatriation, as evidenced by the experiences of the many refugees who have returned to Sri Lanka from Indian camps. ${ }^{25}$ Despite all the attempts to return to Sri Lanka, considerable numbers in India are still reluctant to return, even when the reasons for their flight have abated. The Sri Lankan Tamil refugees are reluctant to return because they are uncertain about having a home, adequate transportation, Tamil-based education system, or health care facilities in the Tamil majority areas. ${ }^{26}$ Like any other repatriation process, the repatriation of Sri Lankan Tamil refugees is a complex and multi-level (individual/family/community) endeavour. However, the concept of repatriation for Sri Lankan Tamil refugees must be contextualized to their community needs because no single, generally accepted definition of repatriation can encapsulate the unique context of each refugee population. Within the efforts of the Sri Lankan government and agencies working with Sri Lankan Tamil refugees in Indian refugee camps, the lack of a concrete 
and transparent repatriation program for Sri Lankan Tamil refugees remains a significant gap. ${ }^{27}$ In order to develop a repatriation program, the Sri Lankan government and nongovernmental agencies need a foundational framework to guide their endeavours.

A review of the literature identified a multitude of issues that prevent migrants from repatriating, including the "complexity of repatriation process, demographic characteristics of migrants, duration of stay in a host country, social connection with home country, reintegration in the home country, and social, economic and political support from home country." ${ }^{28}$ Most of the literature offers insight on migrant populations generally without discussion of the context that shapes the experiences of specific refugee populations. However, the authors examined the results of two of their studies of the Sri Lankan Tamil refugee situation, which offer foundational concepts for discussion of Sri Lankan Tamil refugee repatriation. The third author and a colleague conducted a primary case study analysis, and secondary data analysis of "district-wide refugee population data" (2005-10) from the Department of Rehabilitation of Tamil Nadu (DRTN) to assess support resources for Sri Lankan refugees in India, rehabilitation mechanisms, and livelihood options in Sri Lanka. ${ }^{29}$ Researchers collected the primary data through twelve case study analyses during 2010. Secondary data collected from DRTN's field survey, comprising 100 sample households, was also conducted in 2010. Both primary and secondary data collection were carried out in the Puzhal refugee camp in the Thiruvallur district, and Thenpallipattu refugee camp in Thiruvannamalia district in Tamil Nadu. These camps were selected for the field survey because they account for 13 per cent of the total refugee population in the state. $3^{\circ}$ Both camps have been in existence for over two decades, have similar household characteristics, and have fewer security issues than other camps. $^{31}$ The data included demographic characteristics, family characteristics, possession of identity documents for repatriation, ability and willingness to access and utilize social services, availability of employment outside camp, and children's education and social networks in India. Among the concerns that Sri Lankan Tamil refugees have about repatriation are education, employment, and accessibility of social and family support services. Data analysis indicated that if Sri Lanka cannot provide infrastructure and livelihood options for Tamil repatriates, integrating Tamil refugees into local Indian society could be a durable solution for their future, especially for those who married Indian citizens and wish to remain in India. ${ }^{32}$

The first author and colleagues conducted a qualitative research study with Sri Lankan Tamil refugees who were willing to discuss their repatriation plan..$^{33}$ Researchers used in-depth, semi-structured interviews to generate data in order to understand readiness for repatriation to Sri Lanka and challenges related to repatriation, and to conceptualize strategies to promote successful repatriation. In 2013, researchers in this study selected fifteen refugees from the Gummidipoondi, Erode, Thiruchirappilli, and Thirunelveli refugee camps in the state of Tamil Nadu, India. Participants came to India during the 1984, 1990, or 2006 migration waves and comprised a sample of 60 per cent males and 40 per cent females with an average age of thirty years of age. All participants were living with families, ${ }^{34}$ and all interviews were conducted in Tamil and lasted forty-five minutes. The interview guide focused on six general areas: awareness about repatriation to Sri Lanka, community support for repatriation, concerns regarding repatriation, community leadership to address repatriation concerns, resources to support repatriation to Sri Lanka, and strategies to address challenges to repatriation. Questions within each area were open-ended and designed to elicit a broad range of views and opinions from participants. Interview transcripts and field notes were analyzed by the research team after each interview. The researchers found that Sri Lankan Tamil refugees were concerned about Sri Lanka's lack of a concrete repatriation plan. Tamil refugees also identified primary challenges of repatriation: lack of livelihood options and infrastructure development, lack of interventions to address intergenerational conflict, lack of knowledge of the Sinhalese language, and challenges associated with restoring trust between the Sri Lankan government and Tamils. 35

A deeper exploration of these results allowed the authors to identify key themes with operational definitions in order to propose a conceptual model of repatriation success for Sri Lankan Tamil refugees. Further analysis of these key themes within the proposed conceptual framework could also assist the Sri Lankan government and non-governmental agencies in developing a coherent repatriation strategy.

\section{Proposed Conceptual Framework of Repatriation Success for Sri Lankan Tamil Refugees}

Voluntary repatriation to country of origin can be considered re-establishment of conditions before displacement, not only for the host country, but also for the refugees themselves who feel that it is an end of the refugee cycle. ${ }^{36}$ However, a well-developed repatriation strategy should move away from the idea of one-way movements and solutions. ${ }^{37}$ If repatriation programs are not focused on unique refugee population needs, the return may be more traumatic than the experience of flight and exile itself. ${ }^{38}$ Bradley discusses the need for a more in-depth examination of the conditions of repatriates and revival of repatriation programs. ${ }^{39}$ She argues that repatriation programs need to focus on land 
restitution, suggesting that they must promote repatriates' position in society by placing them on an equal footing with their non-displaced counterparts in order to contribute peace and stability and ensure sustainability of repatriates. ${ }^{40}$

The absence of models specific to repatriation success hinders understanding of Tamil refugee repatriation and effective interventions to address these challenges. On the basis of two research results, the authors of this study propose a conceptual framework of repatriation success that is central to the key themes for Sri Lankan Tamil refugees: livelihood development, cultural and linguistic awareness, social relationships, and a nation with equal citizenship. Subthemes will be discussed under each section.

\section{Livelihood Development}

Although repatriation involves social, cultural, political, and personal adjustment, establishing a new economic basis often becomes important and challenging..$^{41}$ Although there are few studies on the integration of returnees to their country of origin, the literature suggests considerable variation in levels of economic adjustments amongst repatriates. Tamil refugees identified lack of livelihood options such as housing, education, health, and employment as the major challenges they may face in Sri Lanka. ${ }^{42}$ Tamil refugees have a limited but comfortable life in Indian refugee camps. Approximately 150,00o Sri Lankan refugees officially reside in the Indian state of Tamil Nadu. ${ }^{43}$ Refugees who live inside the refugee camps receive monthly financial support, free access to medical services, free public education for refugee children until twelfth grade, and access to a specific number of seats allocated to refugee children in Tamil Nadu universities. ${ }^{44}$ Compared to these supports available to refugees living in Indian camps, Tamil repatriates in Sri Lanka receive minimal support from the Sri Lankan government. Repatriates' ability to transfer their livelihood assets and skills acquired during exile or to practise their pre-exile profession when returning to their homeland can be a positive factor in repatriation. When no or limited livelihood resources are available or transferable, repatriates are likely to face economic hardships upon return. ${ }^{45}$ Farming and fishing would be the main sources of employment income for Tamils who repatriate to Sri Lanka, but after the civil war, Sri Lanka has limited infrastructures such as machines, seeds, or money for these industries, which means that Tamil repatriates may need more options than currently available for a sustainable livelihood. ${ }^{46}$ One Tamil refugee explained, "People from Vavunia [a region of Sri Lanka] are most familiar with farming. They need necessary infrastructure to start farming; seeds, tractors, money, it will take one year to settle farming. So, living has to be supported by government."47

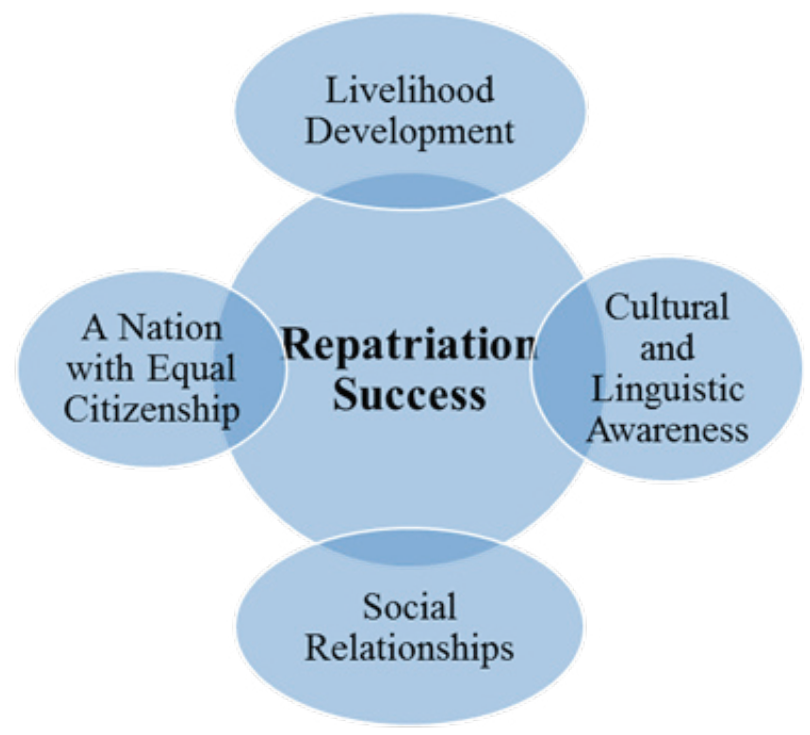

Figure 1. Conceptual framework of repatriation success for Sri Lankan Tamil refugees

Repatriation packages offered by the Sri Lankan government to Tamil refugees are inadequate for developing sustained economic activities among Tamil repatriates. Participants claimed that the resources available to Tamil refugees from the Sri Lankan government and the United Nations High Commissioner for Refugees is a combined 10,000 rupees (approximately us $\$ 160.00$ or $€ 130.00$ ) in the form of a one-time payment, as well as a six-month supply of clothing and food. ${ }^{48}$ In contrast, resources needed to develop livelihood for Tamils in Sri Lanka include housing, farmland, temporary income until farming is resumed, and farming machinery. 49 Sri Lankan Tamil refugees have also reported that the Sri Lankan government acquired most of the refugee houses and land during the civil war, with no apparent intention of returning the land and houses to their previous owners..$^{\circ}$ Because Tamil refugees no longer have property in Sri Lanka, many Tamil refugees, especially those from the older generation, have concerns about building a new life after repatriation. One Tamil refugee explained, "No house or anything there. We have to go there empty-handed. We have jobs here. We made some money. When we reach there, we have to find a job. What kind of job I am going to get? There are no factories, no farms, no place to sleep." 51

The younger generation also worries about their future in Sri Lanka since their Indian-based education is not accepted in Sri Lanka. For example, "It is not easy for children to 
get into Sri Lankan education system, because, first, they have to learn Sinhalese," ${ }^{2}$ which makes children of repatriates fall behind in Sri Lankan schools. ${ }^{53}$ Studies done by Huber and Nowotny discussed the importance of accepting repatriates' education from their host country to continue their education or find employment in their country of origin after repatriation. ${ }^{54}$ Borjas and Brasberg also identified that the least-trained individuals will be the first to return to their homeland, because they believe they do not need much training to get jobs in their country of origin. 55 This study also identified that repatriates who have an economic advantage and know that they can live below their means in their home country also chose to repatriate..$^{5}$ Similar to employment and education challenges, the Sri Lankan civil war destroyed many health-care facilities. Areas like Jaffna and Killinochchi, the Tamil majority areas, still lack facilities to provide care for Tamil families. Therefore, when the Sri Lankan government provides repatriation resources, it is important to prioritize rebuilding medical clinics to provide treatment for Tamil families. ${ }^{57}$

The lack of livelihood options in employment, housing, education, and health represent significant barriers for repatriation to Sri Lanka. Unless Sri Lanka plans to expand livelihood options, these repatriation challenges will persist, creating further conflict for economic benefits between Sinhalese, the majority population, and Tamils, the minority population, in Sri Lanka. For these reasons, it is imperative to include the category "livelihood development" in the proposed conceptual framework of repatriation success. The proposed framework intends to encourage the Sri Lankan government to develop programs to support Tamil repatriates in securing sustainable livelihoods in Sri Lanka.

\section{Cultural and Linguistic Awareness}

Culture and language awareness could facilitate social relationships, which will ease repatriation struggles of migrants..$^{8}$ Improved social relationships between Tamils and Sinhalese will facilitate the reintegration of Tamils into Sri Lankan society through employment, education, housing, and health-care services. The ability to speak in the primary language of a community is crucial to repatriation. 59 Most Sri Lankan Tamil refugees do not speak Sinhalese, which is the primary language of the Sri Lankan Sinhalese community and one of the official languages of Sri Lanka. ${ }^{60}$ While both Tamil and Sinhalese are official languages of Sri Lanka, the Sinhalese community primarily speaks in Sinhalese. The lack of proficiency in Sinhalese constitutes a significant language barrier, which makes repatriation to Sri Lanka impossible for some Tamil refugees. ${ }^{61}$ The Sri Lankan government made both Sinhalese and Tamil official languages of the country in order to enable Sri Lankan
Tamils to apply for administrative, educational, and other sector services in the country. However, Sri Lankan Tamils' apprehension is that the north and east of Sri Lanka where the majority of refugees would return have few administrative, educational, and others infrastructures necessary to find employment. Moreover, many members of the younger generation of Tamil refugees consider themselves culturally and linguistically Indian, thus they perceive repatriation as a departure from their adopted culture. ${ }^{62}$ Members of the older generation chose to repatriate for the aforementioned reasons, but members of the younger generation often prefer to remain in the host country where they feel most socially connected. ${ }^{63}$ However, the Indian government refused to grant Indian citizenship to Sri Lankan Tamil refugees. Although Tamil refugees are upset about the decision to withhold citizenship, they acknowledge the intense support that India has provided to Tamil refugees during their time of crisis. On the other hand, the lack of linguistic and cultural knowledge about Sri Lanka among younger Tamil refugees has resulted in a distant relationship with Sri Lanka: "If I speak Tamil, I will get a job in India, but if I speak Tamil, I won't get a job in Sri Lanka. Even if we learn Sinhalese, we still won't get a job in Sri Lanka because Sri Lanka is still suspicious of Tamils." 64

Tamil refugees believe in sharing their culture with members of the Sinhalese community, because they believe that cross-cultural interaction promotes mutual understanding and contributes meaningfully to the integrated Sri Lankan community. ${ }^{65}$ However, Sri Lankan governmental policies imply that members of the Sri Lankan government, the majority of whom are Sinhalese, would prefer that the Tamil community practise their cultural traditions privately, rather than sharing them with the Sinhalese community. ${ }^{66}$ Therefore, in order to promote successful integration of repatriated Tamils, government policies must demonstrate respect for the unique cultural contributions that both the Sinhalese and Tamil communities offer to the cultural landscape of Sri Lanka. Consequently, the proposed conceptual framework of repatriation success for Sri Lankan Tamil refugees highlights the imperative to communicate in Tamil along with Sinhalese to encourage social cohesion between Tamils and Sinhalese in Sri Lanka.

\section{Social Relationships}

Djajic found that family relationships and connection with the homeland are highly influential for those considering repatriation, although generational differences are also apparent. ${ }^{67}$ Repatriation involves developing and sustaining social relationships within the Tamil community, social connections between Tamils and Sinhalese, and a feeling of safety and stability in Sri Lanka. ${ }^{68}$ To develop a sense of 
belonging to Sri Lanka, Tamils first must form social relations within their own community. Hathaway notes that repatriation is likely to be unsuccessful without the presence of social connections in the homeland, contributing to indefinite lengths of "refuge warehousing." 69 Homans proposed that "the more frequently persons interact with one another, the stronger their sentiments of friendships for one another are apt to be."7o In their research, Wellman and Wortley assert that kin appear to be primary sources of support, while residential proximity proved essential in supporting transactions involving material aid..$^{11}$ Many refugees value living in close proximity to their family because it enables them to share cultural practices and maintain familiar patterns of relationships..$^{72}$ For example, because it is traditionally the responsibility of male children to care for the elders in Sri Lankan families, many male refugees plan to return to Sri Lanka in order to fulfil their obligation to the family. As one male refugee explained, "I am the oldest of nine siblings. All my brothers and sisters are living in Sri Lanka. So it's my duty to go back."73 As other scholarly works have noted, repatriates became linked to local labour markets through their specific networks of interpersonal and organizational ties. ${ }^{74}$ They forged their own "social world." 75 Most obtained their current position through "strong ties,"76 such as their relatives or long-time family friends. Members of the younger generation of Tamil refugees emphasize their lack of social connection with people in Sri Lanka, even fellow Tamils: “I don't want to go; my life is here; my friends are here; I have distant family there, but, I have no connection with them."77

Another disconnection within Tamil refugee populations includes the fact that Tamil refugees continue to discriminate against Tamils who fought for the Liberation Tigers of Tamil Eelam (LTTE), a self-declared Tamil independence group..$^{78}$ Tamils are suspicious of former members of LTTE, which makes it difficult for them individuals to find employment or get married. Negative relationships within the same ethnic group can negatively affect the emotional well-being of individual community members, indicating the need for improved social connections within the Sri Lankan Tamil community as part of a successful repatriation plan. ${ }^{79}$

In addition to addressing tensions between Tamils, successful repatriation will also require improved social connections between Tamils and Sinhalese, resolving the social exclusion that Tamil refugees experience upon returning to Sri Lanka. A social connection may be conceptualized as the social process that ultimately links one with his or her social network members. ${ }^{80}$ As mentioned by Willems, social connections and relationships between Tamils and Sinhalese could support the refugees. ${ }^{81}$ The fact that the majority Sinhalese perceive Tamil refugees negatively also influences the decision-making of Tamils considering repatriation to Sri Lanka. Sri Lankan Tamil refugees have experienced positive outcomes as a result of their social connection with the Indian community, despite differences in culture and country of origin. ${ }^{82}$ One refugee commented, "My cousin who repatriated to Sri Lanka told me that Sinhalese don't like us, they don't talk to us or give employment in any of their stores. If we work together we can do business together, but they don't trust us. They don't want to be our friends." 83 This statement suggests that Tamil refugees would greatly value the recognition and support of Sinhalese. Williams discovered that social networks are channels par excellence through which refugees are able to rebuild their livelihoods in a new and unfamiliar environment, and they provide help to refugees. ${ }^{84}$ Therefore, the discouraging dearth of Sinhalese support for Tamils is a concern for refugees considering repatriation. In order to ensure successful repatriation, increased positive social relationships must occur between the Tamil repatriates and the Sinhalese community in Sri Lanka.

The theme of safety and stability highlights another important factor for facilitating social connection and local integration of Tamil refugees. Information about safety and security may also influence decisions about repatriation. Bradley argued that political agendas have taken priority over human security. ${ }^{85}$ Many Tamil refugees have reported hearing about serious violations of safety and security, especially against women, in Sri Lanka. ${ }^{86}$ In the context of information, social connections and social relations are the most trusted sources of information. They are perceived to provide refugees with the most reliable and current information. ${ }^{87}$

The victimization of refugee women has significant implications for repatriation. Tamil refugees have indicated that if they did not feel physically safe and stable in Sri Lanka, they would feel unable to integrate with the Sri Lankan community. ${ }^{88}$ According to one Tamil refugee, "[There is] no security there [in Sri Lanka]. Lots of assault cases against women; no security to support the safety of women." 89 The Sri Lankan civil war started in response to violations of basic safety, so current experiences of insecurity could contribute to a decreased quality of life for Tamils in Sri Lanka and lead to additional violence. ${ }^{90}$ Further, lack of safety at the time of advocating for the voluntary return of refugees to their countries of origin can be disputed by human rights and refugee law. While this is not directly applicable to India or Sri Lanka, since neither signed the 1951 United Nations Refugee Convention, the principles relating to the ethical dilemma of refoulement must inform a conceptual framework for Tamil repatriation to Sri Lanka. ${ }^{91}$ Therefore, the Sri Lankan government must develop strict policies and programs specifically 
to address safety and security in Sri Lanka, which will in turn promote increased integration of Tamil refugees. For example, housing can promote social activities, safety, security, and stability for Tamil repatriates in Sri Lanka. Having a home in a Sri Lankan community can increase overall physical and emotional well-being of refugees..$^{22}$ Hence, the proposed framework of repatriation success accentuates building social connections with local residents and neighbours to help Tamil refugees feel safely settled in Sri Lanka, as this will provide a range of connections and a sense of belonging, which are important for well-being.

\section{A Nation with Equal Citizenship}

Tamil refugees are apprehensive about securing equal citizenship upon repatriation to Sri Lanka. Their concern reflects the different understanding of equal citizenship among Tamils and Sinhalese. Most influential are the actions of the home country government; policies and resources to support repatriation represents the most significant factor affecting refugees' decision to repatriate. ${ }^{93}$ In the current political context it seems important to encourage dialogue and exchange of opinions between Sinhalese and Tamils, which alone can make for good will on both sides.94 After thirty years of war and violence, it is important that new conversations take place which help to build support for the Tamil refugee repatriation. 95 Overzealous nationalism of either the Sinhala or the Tamil kind is clearly not the way to do this, especially when neither thrives on intolerance and prejudicial hatred. And today, when Sri Lankans as a whole must engage with loss and death on a massive scale, and with the memory of terror, by the state and the militants, a politics based on old certainties will not help the healing or create the context for something fresh and unexpectedly life-affirming to emerge.

In principle, the protection of repatriated citizens is a task for the government in the country of origin. ${ }^{96}$ However, when refugees go back to fragile post-conflict states, governments normally have very little capacity to provide adequate support for repatriates to restore viable subsistence. ${ }^{97}$ For any voluntary repatriation program to be successful in Sri Lanka, the Sri Lankan government must recognize Tamils as citizens in equal standing with Sinhalese and acknowledge the Tamil language and culture as equal in importance to the Sinhalese language and culture. Tamil refugees do not want to return to Sri Lanka to become second-class citizens. ${ }^{98}$ A Tamil recalls his heritage in Sri Lanka with pride: "Sri Lanka is my home country; that's where I was born and brought up. That's where my parents were born and brought up."99 Tamils want respect from the Sri Lankan government. A number of Tamil refugees also pointed out that the establishment of equal rights may have an impact on the way people view them; where there are no equal rights, there is less respect.

Most importantly, inclusivity and responsible citizenship must be an ongoing part of designing and developing repatriation programs. Proactive human rights legal work that seeks to protect the inclusivity of both Tamils and Sinhalese is imperative for Sri Lanka's development. Ponni states that younger generations are tired of prejudice, hatred, and war and would like a different politics where it is possible to talk across differences of race, religion, and language. ${ }^{100}$ It is important to build bridges through community engagement to secure support for a fair and just resolution for Tamil repatriation. While proposing recognition of state accountability for past wrongs, Bradley's work emphasized each state's responsibility to build a constructive relationship between repatriates and the state through responsible citizenship. ${ }^{101}$ Repatriation programs where Sri Lankan Tamil refugees can take up roles in developing projects that arise from their own community needs, will be a positive example of responsible citizenship. Responsible citizenship is the building block of equality and long-term stability. This approach would make them not merely refugees but rather citizens with rights. ${ }^{102}$ States should engage with the repatriate community to develop repatriation programs that utilize their leadership skills and unique cultural and traditional practices. For example, Tamil refugees feel violated when the Sri Lankan government makes decisions regarding Tamil repatriation without engaging with the Tamil refugee community. One Tamil refugee explains,

My younger brother is studying in a college here [in India]. When we go back to Sri Lanka, we don't know if he will get a job there because he doesn't speak Sinhalese, and he doesn't know anything about Sri Lanka. My older brother moved there [to Sri Lanka]. But he wants to come back here [to India]. He is an engineer. Sri Lankan companies didn't give him any jobs because he can't speak fluent Sinhalese. The Sri Lankan government didn't give him a job with any repatriation development projects for Tamils either, which is somewhere he could work because we all speak Tamil. They are deliberately trying to put us in poverty. ${ }^{103}$

There are widespread, negative examples of the failure of the Sri Lankan government to support access to services for Tamil refugees. It is generally acknowledged in policy and practice that connecting refugees to relevant services is a major task in supporting repatriation. ${ }^{104}$ Accordingly, the proposed conceptual framework of repatriation success for Tamil refugees emphasizes the restoration of trust between Sri Lanka and citizens in the hope that increased trust will lead to full and equal engagement of both Tamils and Sinhalese in Sri Lanka. When Sinhalese and Tamils are able 
to trust and understand each other, their true perceptions of each other, and the importance of connecting with each other, they will become interdependent. In an interdependent society, the transformation of one can lead to the transformation of all. If Sinhalese and Tamils work together, they might gain respect for each other, affirming their mutual need for each other. This integration could become the catalyst for the kind of change that radically transforms the nation of Sri Lanka.

\section{Verification of Proposed Framework}

When proposing a framework or a program for Sri Lankan Tamil refugees, one must seek the support, guidance, and suggestions of Tamil refugees. The authors sought consultations with Tamil refugee elders, academics, researchers, policymakers, and local-level practitioners. Representatives from the Organization for Eelam Refugee Rehabilitation and Sri Lankan Tamil refugee elders from Trichy and Gummidipoondi refugee camps assessed the meaningfulness and utility of the framework, confirming that the key concepts of the framework reflected the salient features of Sri Lankan Tamil refugee repatriation. The authors also presented the framework in two conferences (local and international) with policymakers and practitioners from government, academic, and social services. When finalizing the framework of repatriation success, the authors incorporated feedback on the relevance of the concepts from the seminar and conferences to contextualize the repatriation framework to Sri Lankan Tamil refugees.

\section{Conclusion}

This article proposed a conceptual framework of repatriation success for Sri Lankan Tamil refugees. Elements of the framework were identified from the findings of two specific scientific studies conducted with Sri Lankan Tamil refugees in Indian refugee camps. Key concepts that emerged through this process were then verified by Sri Lankan Tamil refugee elders, academics, practitioners, and policymakers. The conceptual framework of repatriation success specifies sub-concepts under the key concepts that shaped conceptualization of successful repatriation.

The identification of each key concept raises significant questions regarding repatriation. First, interdependence of these themes (livelihood, cultural and linguistic knowledge, social connection, and nationhood) should be highlighted. For example, the authors' literature analysis identified lack of livelihood options as the most commonly reported repatriation challenge. ${ }^{105}$ Stable housing can help refugees establish continuous relationships with their neighbours and other local residents. However, the inability to communicate in Sinhalese can hinder the ability to learn cultural knowledge from neighbours, contributing to a lack of social connection among refugees. Second, the conceptual framework of repatriation success encourages social relationships between the Tamil and Sinhalese communities, while also promoting their unique cultural identities and languages. Third, a nation with equal rights for both the Tamil and Sinhalese communities promotes equal citizenship and social cohesion, rather than assimilation to a single mainstream culture and potential ongoing exclusion of an ethnic minority. ${ }^{106}$ These engagements should be fully integrated into the repatriation framework. Any conceptual framework related to repatriation can incite debate, but it can also provide a structural foundation for thoughtful conversation about how best to accomplish the goals of repatriation.

\section{Notes}

1 Stanley Tambiah, Buddhism Betrayed?: Religion, Politics, and Violence in Sri Lanka (Chicago: University of Chicago Press, 1992): 98-107.

2 Ibid.

3 Ibid.

4 C. Valatheeswaran and Sebastian Irudaya Rajan, "Sri Lankan Tamil Refugees in India: Rehabilitation Mechanisms, Livelihood Strategies, and Lasting Solutions," Refugee Survey Quarterly 30 (2011): 24-44.

5 Ibid.

6 Ibid.

7 Ibid.

8 Sri Lankan Ministry of Prison Reforms, Rehabilitation, Resettlement and Hindu Religious Affairs, "Voluntary Repatriation of Refugees of Sri Lankan Origin," 31 March 2016, http://resettlementmin.gov.lk/site/index. php?option $=$ com_content $\&$ view $=$ article $\& i d=4 \& I t e m i d=1$ 9\&lang=en.

9 Mike Sanderson, “The Role of International Law in Defining the Protection of Refugees in India," Wisconsin International Law Journal 33, no. 1 (2015): 46-109.

10 Kamayani, "Why India Won't Sign Refugee Treaty," Kractivism: Bridge the Gap Bring the Change (blog), 13 September 2015, http://www.kractivist.org/ why-india-wont-sign-refugee-treaty/.

11 UNHCR, "2015 UNHCR Global Appeal Update-South Asia," http://www.unhcr.org/5461e6oa54d.html.

12 Nafees Ahmad, "Refugees: State Responsibility, Country of Origin and Human Rights," Asia-Pacific Journal on Human Rights \& the Law 10, no. 2 (2009): 1-22.

13 Valatheeswaran and Rajan, "Sri Lankan Tamil Refugees in India."

14 James Hathaway and R. Alexander Neve, "Making International Refugee Law Relevant Again: A Proposal for Collectivized and Solution-Oriented Protection," Harvard Human Rights Journal 10 (1997): 115-211. 
15 Manohari Velamati, "Sri Lankan Tamil Migration and Settlement: Time for Reconsideration," India Quarterly 65, no. 3 (2009): 271-91; Sanderson, "Role of International Law"; UNHCR, "2015 UNHCR Subregional Operations Profile."

16 John La, "Forced Remittances in Canada's Tamil Enclaves," Peace Review 16, no. 3 (2004): 379-85; Velamanti, "Sri Lankan Tamil Migration and Settlement."

17 Danielle C. Sepulveda, "Challenging the Assumptions of Repatriation," Courier 150 (March-April 1995): 83-5.

18 Velamanti, "Sri Lankan Tamil Migration and Settlement."

19 John Giammatteo, "To Return or Stay?," Forced Migration Review 35 (2010): 52.

20 Vincent Chetail, "Voluntary Repatriation in Public International Law: Concepts and Contents," Refugee Survey Quarterly 23, no. 3 (2004): 1-32; UNHCR, "2015 UNHCR Subregional Operations Profile."

21 Tim Allen, "Introduction," in In Search of Cool Ground: War, Flight and Homecoming in Northeast Africa, ed. Tim Allen (London: James Currey/Africa World Press, 1996), 96-111.

22 Abhijit Dasgupta, "Repatriation of Sri Lankan Refugees: Unfinished Tasks," Economic and Political Weekly 38 (2003): 2365-7.

23 D. Warner, "Voluntary Repatriation and the Meaning of the Return to Home: A Critique of Liberal Mathematics," Journal of Refugee Studies 7, nos. 2-3 (1994): 160-75.

24 Kamayani,"Why India Won't Sign Refugee Treaty?"

25 Anders H. Stefansson, "Under My Own Sky? The Cultural Dynamics of Refugee Return and (Re)integration in PostWar Sarajevo" (Ph.D-række nr 25, Institut for Antropologi, Københavns Universitet, 2003).

26 Giammatteo, “To Return or Stay?”

27 Dasgupta, "Repatriation of Sri Lankan Refugees."

28 S. Agblorti, "Refugee Integration in Ghana: The Host Community's Perspective," Working Paper no. 203, New Issues in Refugee Research, UNHCR, 2011; M. Bradley, "Unlocking Protracted Displacement: Central America's 'Success' Story Reconsidered," Working Paper no. 77, Refugee Studies Centre, University of Oxford, 2011; D. Chatty and N. Mansour, "Unlocking Protracted Displacement: An Iraqi Case Study," Rsc Working Paper no. 78, Refugee Studies Centre, University of Oxford, 2011; S. Dick, "Liberians in Ghana: Living without Humanitarian Assistance," Working Paper no. 57, New Issues in Refugee Research, UNHCR, 2002; K. Long, "Extending Protection? Labour Migration and Durable Solutions for Refugees," Working Paper no. 176, New Issues in Refugee Research, UNHCR, 2009; Laura Hammond, Safety, Security and Socio-Economic Wellbeing in Somaliland (Nairobi, Geneva, London: SOAS-University of London, DDG, GICHD, 2013), http:// eprints.soas.ac.uk/17411/1/sOAS\%2ODDG\%2oReport.pdf.

29 Valatheeswaran and Rajan, "Sri Lankan Tamil Refugees in India."

30 Ibid., 27.

31 Ibid.
32 Ibid.

33 Miriam George, Wendy Kliewer, and Sebastan Irudaya Rajan, "Rather than talking Tamil, they should be talking to Tamils': Sri Lankan Tamil Refugee Readiness for Repatriation," Refugee Survey Quarterly 34, no. 2 (2015): $1-22$.

34 Ibid.

35 Ibid.

36 R. Black and K. Koser, "The End of Refugee Cycle?," in The End of the Refugee Cycle?, ed. Black and Koser, 2-17 (Oxford: Berghahn Books, 1999).

37 George, Kliewer and Rajan, "Rather than talking Tamil.”

38 Katy Long, "Home Alone? A Review of the Relationship between Repatriation, Mobility, and Durable Solutions for Refugees," United Nations High Commissioner for Refugees Policy Development and Evaluation Services, 2010, http://www.unhcr.org/4b97afc49.html.

39 Megan Bradley, Refugee Repatriation: Justice, Responsibility and Redress (Cambridge: Cambridge University Press, 2013), 304 .

40 Ibid.

41 Danielle C. Sepulveda, "Challenging the Assumptions of Repatriation," Courier 150 (March-April 1995): 83-5.

42 Valatheeswaran and Rajan, "Sri Lankan Tamil Refugees in India."

43 C. Tapscott, "A Tale of Two Homecomings," in When Refugees Go Home, ed. T. Allen and H. Morsink, 251-9 (Trenton, NJ: African World, 1994).

44 J. Jackson, "Repatriation and Reconstruction in Zimbabwe during the 1980s," in Allen and Morsink, When Refugees Go Home, 126-66.

45 Valatheeswaran and Rajan, "Sri Lankan Tamil Refugees in India."

46 Ibid.

47 Ibid.

48 Ibid.

49 George, Kliewer and Rajan, "'Rather than talking Tamil.”

50 Valatheeswaran and Rajan, "Sri Lankan Tamil Refugees in India."

51 George, Kliewer, and Rajan, "'Rather than talking Tamil.” 52 Ibid., 12.

53 Ibid.

54 Peter Huber and Klaus Nowotny, "Return Intentions among Potential Migrants and Commuters: The Role of Human Capital, Deprivation and Networks" (Vienna: Austrian Economic Research Institute, 2009).

55 George Borjas and Bernt Bratsberg, "Who Leaves? The Outmigration of the Foreign-Born," Review of Economics and Statistics 78 (1996): 165-76.

56 Ibid.

57 George, Kliewer, and Rajan, “Rather than talking Tamil.”

58 Valatheeswaran and Rajan, "Sri Lankan Tamil Refugees in India."

59 Alastair Ager and Alison Strang, "Understanding Integration: A Conceptual Framework," Journal of Refugee 
Studies 21 (2008): 166-91; Miranda Alison, "Armed Violence and Poverty in Sri Lanka: A Mini Case Study for the Armed Violence and Poverty Initiative," 2004, https:// bradscholars.brad.ac.uk/handle/10454/1004; Council of Europe (COE), Measurement and Indicators of Integration (Strasbourg: COE, 1997); Institute of Development Studies, "Sustainable Rural Livelihoods: Practical Concepts for the 21st Century," 2003, http://www.ids.ac.uk/publication/ sustainable-rural-livelihoods-practical-concepts-for-the21st-century.

60 George, Kliewer, and Rajan, "'Rather than talking Tamil.”"

61 Ibid.

62 Ibid.

63 S. Djajic, "Immigrant Parents and Children: An Analysis of Decision Related to Return Migration," Review of Developmental Economics 12, no. 3 (2008): 469-85.

64 George, Kliewer, and Rajan, "Rather than talking Tamil," 12.

65 Ibid.

66 Ibid.

67 Djajic, "Immigrant Parents and Children."

68 George, Kliewer, andRajan, "Rather than talking Tamil.”

69 Hathaway and Neve, "Making International Refugee Law Relevant."

70 Melvin B. Mogulof, David G. French, Leonard M. Bloksberg, and Walter F. Stern, "Homans' Theory of yhe Human Group: Applications to Problems of Administration, Policy, and Staff Training in Group Service Agencies," Journal of Jewish Communal Service 40, no. 4 (1964): 381.

71 Barry Wellman and Scott Wortley, "Different Strokes from Different Folks: Community Ties and Social Support," American Journal of Sociology 96, no. 3 (1990): 558-88.

72 George, Kliewer, and Rajan, "'Rather than talking Tamil." 73 Ibid., 10.

74 M. V. Poros, "The Role of Migrant Networks in Linking Local Labour Markets: The Case of Asian Indian Migration to New York and London," Global Networks 1, no. 3 (2001): 243-59.

75 E. Mark, "The Social World of Refugees: A Conceptual Framework," Journal of Refugee Studies 3, no. 3 (1990): 189-203.

76 M. Granovetter, “The Strength of Weak Ties," American Journal of Sociology 78, no. 6 (1973): 1361.

77 George, Kliewer, and Sebastan Rajan, "Rather than talking Tamil," 10.

78 Ibid.

79 D. T. Gurak and F. Caces, "Migration Networks \& Shaping of Migration Systems," in Internal Migration, ed. M. M. Kritz, L .L. Lim, and H. Zlotonik, 150-76 (Oxford: Clarendon, 1992); M. Kritz and H. Zlotnik, "Global Interactions: Migration Systems, Processes, and Policies," in International Migration Systems: A Global Approach, ed. M. Kritz, L. Lim, and H. Zlotnik, 1-16 (Oxford: Clarendon, 1992).
80 K. Koser and C. Pinkerton, The Social Networks of Asylum-seekers and the Dissemination of Information about Countries of Asylum (London: Research Development and Statistics Directorate, Home Office, 2002).

81 Roos Willems, "Coping with Displacement: Social Networking among Urban Refugees in an East African Context," in Displacement Risks, ed. Otaru Ohta and Yntiso D. Gebre (Kyoto: Koyto University Press, 2005), 53.

82 George, Kliewer, and Rajan, "'Rather than talking Tamil.” 83 Ibid., 13.

84 H. A. Williams, "Self-Settled Refugees in North-western Zambia: Shifting Norms of Assistance from Social Networks'," in Selected Papers on Refugees Issues: II: 1993, ed. Mary Carol Hopkins and Nancy D. Donnelly, 135-55 (Arlington, va: American Anthropological Association, 1993).

85 Bradley, Refugee Repatriation, 304.

86 George, Kliewer, and Rajan, "Rather than talking Tamil.”

87 John S. Collins, "An Analysis of the Voluntariness of Refugee Repatriation in Africa” (master's thesis, University of Manitoba, 1996).

88 Francesca Hansen, Jean Mutabaraka, and Priscilla Ubricao, "Repatriation, Resettlement, Integration: A Study of the Three Refugee Solutions," Niapele, 2008, http://www.theniapeleproject.org/files/Niapele-ScPoStudy2008.pdf.

89 George, Kliewer, and Rajan, “"Rather than talking Tamil,"” 11.

90 Ibid.

91 UNHCR, "2015 UNHCR subregional operational profile"; Chetail, "Voluntary Repatriation in Public International Law"; Marjoleine Zieck, "Voluntary Repatriation: Paradigm, Pitfalls, Progress," Refugee Survey Quarterly 23, no. 3 (2004): 33-54.

92 Valatheeswaran and Rajan, "Sri Lankan Tamil Refugees in India."

93 Simon McMahon, "Social Attitudes and Political Debate on Immigration: Spanish Perceptions of Romanian Immigrants," Journal of Identity and Migration Studies 5 (2011): 91-115.

94 D. B. S. Jayaraj, "Protesting the Forced Repatriation of Visiting Sports Persons and Others from Sri Lanka," Kafila, 2012, http://dbsjeyaraj.com/dbsj/archives/10286.

95 Ibid.

96 Naohiko Omata, "Struggling to Find Durable Solutions: Liberian Refugees in Ghana," research paper no. 234, New Issues in Refugee Research, UNHCR Policy Development and Evaluation Service, 2012.

97 Long, "Home Alone?"

98 George, Kliewer, and Rajan, "Rather than talking in Tamil."”

99 Ibid., 10.

100 Jayaraj, "Protesting the Forced Repatriation of Visiting Sports Persons and Others." 
101 Bradley, Refugee Repatriation: Justice, Responsibility and Redress.

102 Ibid.

103 George, Kliewer, and Rajan, "Rather than talking Tamil," 20.

104 Michael Lanphier, "The Reception and Resettlement of Vietnamese Refugees in Britain," in The International Refugee Crisis, ed. Vaughn Robinson, 280-90 (Basingstoke: Macmillan, 2000).

105 Ibid.

106 Ager and Strang, "Understanding Integration"; Alison, "Armed Violence and Poverty in Sri Lanka"; Council of Europe (COE), Measurement and Indicators of Integration; Institute of Development Studies, "Sustainable Rural Livelihoods.
Miriam George is an associate professor at the Virginia Commonwealth University School of Social Work. The author may becontacted at mgeorge@vcu.edu.

Anita Vaillancourt is an assistant professor at the University of Fraser Valley School of Social Work and Human Services. The author may be contacted at Anita.Vaillancourt@ufv.ca.

S. Irudaya Rajan is a professor and chair of the Union Ministry of Overseas Indian Affairs Research Unit on International Migration at the Center for Development Studies in India. The author may be contacted at rajan@cds.ac.in. 